\title{
Pengaruh Kemampuan Menyimak dan Penguasaan Kosakata terhadap Kemampuan Menulis Deskripsi
}

\author{
Hujaeni Roup \\ Fakultas Pascasarjana, Universitas Indraprasta PGRI \\ Jalan Nangka No. 58 C/TB. Simatupang, Tanjung Barat, \\ Jakarta Selatan 12530 \\ hujaeniroup02@gmail.com
}

\begin{abstract}
The objective of this research is to know the influence of learning ability and mastering the vocabulary together to the writing skill of descriptive, to know the influence of listening ability to writing skill of descriptive, to know the influence of mastering the vocabulary to the writing skill of descriptive. The sample used sixty students as the research sample by using proportional random sampling technique from all students of MTs in South Jakarta. The collecting of data is done by giving a conceptual comprehension test and distributing the questionnaire. The data analysis consists of instrument testing, research by a validity test, reliability. Then, the analysis rules with normality and homogeneity test are done. The hypothesis test with a double linear regression test. This research is held in March 2018 up to Juli 2018. Based on the result and data analysis, can be concluded as follow. There is a significant influence between listening ability and mastering vocabulary together to the writing skill of descriptive of the students of MTsN in South Jakarta. It is proved by $\mathrm{Sig}=0,001<0,05$ and $\mathrm{F}$ calculation $=83,17$, there is a significant influence between a listening ability to the writing descriptive skill of the students of MTsN in South Jakarta. It is proved by $\mathrm{Sig}=0,000<0,05$ and $\mathrm{t}$ calculated $=2,971$. There is a significant influence between the mastering vocabulary to the writing descriptive skill of the students of MTsN in South Jakarta. It is proved by value of Sig=0.009<0,05 and t calculated $=2,718$.

Keywords: Writing Descriptive Skill, Listening Ability, Mastering Vocabulary.
\end{abstract}

\begin{abstract}
Abstrak
Tujuan penelitian ini adalah untuk mengetahui pengaruh kemampuan menyimak dan penguasaan kosakata secara bersama-sama terhadap keterampilan menulis deskripsi, untuk mengetahui pengaruh kemampuan menyimak terhadap keterampilan menulis deskripsi, untuk mengetahui pengaruh penguasaan kosakata terhadap keterampilan menulis deskripsi. Penelitian ini menggunakan 60 siswa sebagai sampel dengan teknik proposional random sampling dari seluruh siswa MTs Negeri di Jakarta Selatan. Pengumpulan data dilakukan dengan pemberian tes pemahaman konsep dan penyebaran angket. Analisis data terdiri dari pengujian instrumen, uji validitas, dan realibilitas. Selanjutnya dilakukan persyaratan analisis dengan normalitas dan uji homogenitas. Pengujian hipotesis dengan uji regresi linear berganda. Penelitian ini dilksanalan pada bulan Maret 2018 sampai Juli 2018. Berdasarkan hasil dan analisis data, disimpulkan beberapa hal sebagai berikut: 1). Terdapat pengaruh yang signifikan antara kemampuan menyimak dan penguasaan kosakata secara bersama-sama terhadap keterampilan menulis deskripsi siswa MTs Negeri di Jakarta Selatan. Hal ini dibuktikan dengan Sig=0,001< 0,05 dan F hitung $=83,17,2)$. Terdapat pengaruh yang signifikan antara kemampuan menyimak terhadap keterampilan menulis deskripsi siswa MTs Negeri di Jakarta Selatan. Hal ini dibuktikan dengan Sig=0,000<0,05 dan $t$ hitung $=2,971,3)$. Terdapat pengaruh yang signifikan penguasaan kosakata terhadap keterampilan menulis deskripsi siswa MTs Negeri di Jakarta Selatan. Hal ini dibuktikan dengan nilai Sig=0,009<0,05 dan $t$ hitung $=2,718$.

Kata Kunci: Keterampilan Menulis Deskripsi, Kemampuan Menyimak, Penguasaan Kosakata
\end{abstract}




\section{PENDAHULUAN}

Menulis merupakan salah satu aspek keterampilan berbahasa yang memiliki peranan penting dalam kehidupan, selain keterampilan berbahasa lainnya seperti menyimak, berbicara, dan membaca. Apalagi pada era globalisasi dan informasi seperti sekarang ini, kemampuan menulis sangat diperlukan. Hal ini bukan berarti pada zaman dahulu keterampilan menulis tidak penting, namun dewasa ini seseorang dituntut kecepatan dan ketepatan dalam bertindak, termasuk kecepatan dan ketepatan dalam menyampaikan informasi secara tertulis. Dalam menghadapi tantangan kemajuan ilmu pengetahuan dan teknologi, maka kemampuan menulis mutlak diperlukan dan terus ditingkatkan.

Mengingat bahwa dalam penentuan kelulusan siswa dari satuan pendidikan diperlukan standar kompetensi kelulusan yang digunakan sebagai pedoman penilaian, maka kompetensi lulusan untuk mata pelajaran bahasa menekankan pada kemampuan membaca dan menulis. Hal tersebut sesuai dengan Peraturan Pemerintah Republik Indonesia Nomor 19 Tahun 2005 tentang Standar Nasional Pendidikan (Pasal 25 Ayat 3) yang menyatakan bahwa kompetensi lulusan untuk mata pelajaran bahasa menekankan pada kemampuan membaca dan menulis sesuai dengan jenjang pendidikan.

Pemerolehan keterampilan berbahasa pada umumnya secara berturut-turut dimulai dari keterampilan mendengarkan, berbicara, membaca, dan menulis. Hal ini sesuai pendapat Iskandarwassid (2015:248), yang mengungkapkan bahwa aktivitas menulis merupakan suatu bentuk manifestasi kemampuan dan keterampilan berbahasa yang paling akhir oleh pembelajar bahasa setelah kemampuan mendengarkan, berbicara dan membaca. Dibandingkan dengan tiga kemampuan berbahasa yang lain, kemampuan menulis merupakan kemampuan berbahasa yang paling sulit dikuasai bahkan oleh penutur asli bahasa yang bersangkutan sekalipun. Hal ini disebabkan kemampaun menulis menghendaki penguasaan berbagai unsur kebahasaan dan unsur di luar bahasa itu sendiri yang menjadi tulisan.

Menulis bukan pekerjaan mudah, namun juga tidak sulit. Menulis adalah salah satu keterampilan berbahasa yang digunakan seseorang untuk berkomunikasi secara tidak langsung dan tidak bertatap muka dengan orang lain. Menulis adalah kegiatan produktif dan ekspresif. Keterampilan menulis tidak diperoleh secara langsung, melainkan melalui latihan dan praktik yang banyak dan teratur ( Tarigan, 2008:3). Menulis merupakan keterampilan berbahasa yang menggunakan ragam bahasa tulis. Menulis merupakan bagian yang tidak dapat dipisahkan dalam sebuah proses belajar yang dialami siswa selama menuntut ilmu di sekolah. Menulis memerlukan keterampilan karena diperlukan latihan yang berkelanjutan. Pembelajaran keterampilan menulis pada jenjang sekolah dasar merupakan landasan untuk jenjang yang lebih tinggi. Siswa MTs diharapkan dapat menyerap aspek-aspek dasar dari keterampilan menulis, sehingga pembelajaran keterampilan menulis pada jenjang sekolah dasar tersebut berfungsi sebagai landasan untuk ketermapilan menulis di jenjang pendidikan berikutnya.

Selain itu, pemilihan kata juga harus diseleksi dengan cermat dan disesuaikan dengan kaidah-kaidah bahasa, sehingga penting sekali penguasaan kosakata bagi siswa. Hal ini sesuai dengan pendapat Tarigan (2008:2), bahwa kualitas keterampilan berbahasa seseorang bergantung pada kuantitas dan kualitas 
kosakata yang dimlikinya. Semakin kaya kosakata yang dimiliki, semakin besar pula kemungkinan terampil berbahasa seperti berbicara dan menulis.

Penguasaan kosakata bagi siswa di MTs Negeri sangat penting untuk praktik berbahasa. Misalnya, untuk menulis sebuah karangan. Secara umum karangan dapat dikelompokkan dalam lima jenis yaitu deskripsi, narasi, ekspoisisi, argumentasi dan persuasi. Wagiran (2005:18), mengungkapkan karangan deskripsi merupakan salah satu jenis karangan yang memberikan efek kepada pembaca. Karangan deskripsi adalah karangan yang menggambarkan suatu objek atau peristiwa dengan sangat jelas, sehingga pembaca seolah-olah dapat merasakan, melihat, atau mengalami sendiri hal yang dibahas dalam karangan. Jenis karangan ini berkaitan dengan panca indra manusia. Karangan ini dikembangkan dengan satu gagasan utama yang diikuti kalimat-kalimat penjelas setelahnya.

Berdasarkan data hasil observasi awal, bahwa terdapat beberapa permasalahan yang terjadi pada siswa kelas VII MTs Negeri di Jakarta Selatan dalam proses pembelajaran bahasa Indonesia pada materi karangan deskripsi, yaitu: (1) siswa bingung menentukan judul karangan deskripsi yang dibuat; (2) rendahnya penguasaan kosakata dan kemampuan menulis karangan deskripsi yang dimiliki oleh siswa; (3) siswa merasa kesulitan menentukan kata yang tepat untuk ditulis dalam sebuah karangan deskripsi; (4) kurangnya kemampuan siswa menggunakan variasi kalimat dalam menulis karangan deskripsi; (5) kurangnya minat siswa pada materi menulis karangan deskripsi; dan (6) rendahnya pemgetahuan siswa pada materi menulis karangan deskripsi.

Kenyataannya, keterampilan menulis deskripsi siswa masih rendah. Hal ini diakui oleh salah seorang guru bahasa Indonesia di MTs Negeri 13 Jakarta Selatan, yang menyatakan bahwa siswa kurang mampu dalam menuangkan ide atau gagasannya ke dalam sebuah tulisan. Penyebab rendahnya keterampilan menulis deskripsi siswa diidentifikasi karena siswa kurang memahami tulisan deskripsi itu sendiri dan kurangnya penguasaan kosakata. Kosakata sebagai salah satu materi pembelajaran bahasa Indonesia di sekolah menempati peran sangat penting sebagai dasar penguasaan siswa terhadap penguasaan dalam materi mata pelajaran bahasa Indonesia. (Kasno, 2014:1)

Data hasil observasi menunjukkan bahwa pengetahuan siswa terhadap karangan deskripsi masih kurang. Ini dibuktikan dengan hanya 40\% siswa yang mampu mencapai batas Standar Ketuntasan Belajar Minimum (SKBM) memperoleh nilai 75 , sementara 35\% siswa mendapat nilai 60 dan $25 \%$ siswa memperoleh nilai 70. Sebagian besar siswa ragu membedakan deskripsi dengan jenis tulisannya.

Pembelajaran menulis deskripsi yang sekarang ini masih menggunakan cara tradisional, sehingga orientasi belajar masih berpusat pada guru dan bukan pada siswa. Permasalahan yang masih adadi sebagian sekolah adalah kurangnya keterlibatan siswa di kelas, karena gurulah yang paling banyak berperan dalam pembelajaran menulis. Selain itu, guru kurang bervariasi dalam pembelajaran menulis deskripsi sehingga siswa mudah bosan dan mengalami kesulitan belajar.

Menurut Guru bahasa Indonesia, bahwa pembelajaran menulis deskripsi di MTs Negeri Jakarta Selatan cenderung membuat siswa merasa malas. Hal ini 
karena kegiatan pembelajaran yang dilaksanakan selama ini dianggap kurang produktif, dalam arti manfaat atau hasil dari pembelajaran menulis deskripsi hanya sebatas pengetahuan bagi siswa dan tidak ada realisasinya dalam praktek pembelajaran sehari-hari. Proses pembelajaran selama ini menunjukkan bahwa banyak siswa MTs Negeri khususnya kelas VII Jakarta Selatan mengalami kesulitan menyatakan pendapat dan mengekspresikan buah pikiran dalam bentuk tulisan, menyusun teks deskripsi sederhana, dan membaca yang mudah dimengerti pendengarnya. Kemampuan dasar untuk menggunakan bahasa Indonesia untuk berkomunikasi belum dapat digunakan secara maksimal.

Sebagai pembelajar harus mengetahui dan dapat menerapkan pengajaran yang dapat dirasa merangsang siswa untuk aktif, kreatif, agar dapat mengembangkan proses pembelajaran yang kondusif sehingga dapat diperoleh hasil yang maksimal. Disamping itu sebagai pembelajar hendaklah dapat mengadakan inovasi pembelajaran. Suprayekti (2006:14), menjelaskan inovasi merupakan suatu ide, hal-hal yang praktis, metode, cara, barang-barang, yang dapat diamati atau dirasakan sebagai sesuatu yang baru bagi seseorang atau sekelompok orang (masyarakat). Jadi, inovasi/ pembaharuan harus dilakukan untuk memecahkan masalah guna mencapai tujuan.

Pengajaran bahasa merupakan proses mengajarkan bahasa dari guru kepada para siswanya. Guru yang baik adalah guru yang mampu menciptakan lingkungan belajar yang menarik, (Arikunto,2009:39). Dengan menciptakan lingkungan yang menarik, maka siswa akan memiliki wawasan yang luas dan mampu mendalami ilmu pengetahuan yang semakin berkembang. Untuk itu, dalam pengajaran dan pembelajaran bahasa diperlukan guru yang mampu memberikan kemudahan belajar bagi seluruh siswa, agar dapat mengembangkan potensi secara optimal. Dalam hal ini, guru harus kreatif, profesional, menyenangkan, menerapkan metode dengan tepat, memiliki kreativitas yang tinggi dan mampu berinovatif, E. Mulyasa, (2009:36).

Pembelajaran yang baik adalah pembelajaran yang dapat mendorong siswa untuk tahu lebih banyak. Belajar harus dirasakan sebagai keperluan,bukan suatu rasa takut dengan guru atau orang tua, dan bukan keterpaksaan yang harus dilakukan, akan tetapi merupakan kesadaran diri dari siswa bahwa belajar merupakan suatu kebutuhan yang wajib dilaksanakan. Sebagai pembelajar hendaklah mampu menciptakan suasana belajar yang menyenangkan, sehingga siswa tidak merasa bosan dalam proses pembelajaran.

\section{METODE}

Penelitian ini dilaksanakan pada siswa MTs Negeri 13 dan MTs Negeri 32 tepatnya pada siswa kelas VII tahun pelajaran 2017/2018. Pemilihan tempat penelitian didasarkan pada pertimbangan tujuan penelitian yaitu mengetahui kemampuan menulis siswa di MTs Negeri di Jakarta Selatan. Penelitian dilakukan dalam dua tahap, tahap pertama dilakukan penelitian pendahuluan yaitu mengumpulkan data terkait dengan jumlah populasi dan jumlah sampel yang akan dijadikan obyek penelitian. Tahap kedua melakukan uji coba instrumen dan 
ditindak lanjuti dengan penelitian. Proses penelitian dilakukan sekitar lima bulan terhitung dari bulan Maret 2018 sampai dengan Juli 2018

Penelitian ini menggunakan metode penelitian survei, yaitu kegiatan penelitian yang dilakukan dengan cara mengumpulkan fakta melalui pengamatan langsung (Nazir, 2003: 56). Penelitian ini menggunakan dua variabel bebas yaitu kemampuan menyimak $\left(\mathrm{X}_{1}\right)$ dan penguasaan $\operatorname{kosakata}\left(\mathrm{X}_{2}\right)$ dan satu variabel terikat yaitu keterampilan menulis deskripsi (Y), sedangkan populasi dalam penelitian ini seluruh siswa kelas VII MTs Negeri 13 dan MTs Negeri 32 Jakarta Selatan tahun pelajaran 2017-2018.

Sampel diambil dengan teknik accidental random sampling. Sampel melibatkan 60 siswa dari seluruh siswa kelas VII pada semester 2 sebanyak 600 orang terdiri dari dari 9 (sembilan) kelas paralel MTs Negeri di Jakarta Selatan. Menurut Ridwan (2004:70), apabila subjek kurang dari 100, maka lebih baik diambil semua, sehingga penelitiannya merupakan penelitian populasi. Selanjutnya jika subjeknya besar dapat diambil antara 10\%-15\% atau 20\%-25\% atau lebih.

Jumlah sampel yang akan diambil dalam penelitian ini menggunakan rumus Slovin, karena ukuran populasi sudah diketahui (Umar, 2009:141). Kuisioner digunakan untuk mengumpulkan data variabel bebas pertama (X1) yaitu kemampuan menyimak, sedangkan tes pilihan ganda digunakan untuk mengumpilkan data variabel bebas kedua (X2) yaitu penguasaan kosakata. Sedangkan tes esai digunakan untuk mengumpulkan data variabel terikat (Y) yaitu ketrampilan menulis karangan deskripsi.

Pengembangan instumen dilakukan melalui beberapa tahap: (1) Menyusun indikator variabel penelitian (2) Menyusun kisi-kisi instrumen (3) Melakukan uji coba instrumen dan (4) Melakukan pengujian validitas dan realibilitas instrumen. Teknik pengumpulan data untuk variabel kemampuan menyimak menggunakan kuisioner dengan menggunakan skala Likert.

Teknik pengumpulan data untuk variabel kemampuan menyimak terdiri 30 soal dan penguasaan kosakata digunakan tes objektif yang terdiri atas 30 soal. Tes untuk penguasaan kosakata berupa pilihan ganda dengan 4 pilihan jawaban, tetapi hanya satu jawaban yang benar. Pilihan jawaban yang benar diberi bobot 1 sedangkan pilihan jawaban yang salah diberi bobot 0 (nol). Penilaian dilakukan dengan skala penilaian dengan rating skala (1 sampai dengan 30 ).

Bentuk butir-butir soal tes disusun dalam pertanyaan yang akan dijawab responden dengan pilihan jawaban sesuai dengan kondisi masing-masing siswa. Instrumen ini antara lain untuk pengukuran kemampuan menyimak (X1) dan pengukuran penguasaan kosakata (X2) dengan variabel terikatnya adalah keterampilan menulis deskripsi (Y) yang diukur dengan tes keterampilan menulis deskripsi.

Selanjutnya instrumen yang disusun tersebut terlebih dahulu diujicobakan untuk dihitung validitas dan reliabilitasnya. Validitas instrumen ini merupakan validitas content atau validitas isi. Hal ini dilakukan dengan tujuan untuk menjamin kualitas instrumen tersebut, pengumpulan data dalam penelitian ini dijelaskan secara rinci masing-masing variabel yang digunakan dalam penelitian ini. 
Kemampuan menyimak adalah skor total jawaban siswa terhadap tes mengenai instrumen menyimak yang disusun berdasarkan indikator yang berhubungan dengan pemahaman isi bacaan, penafsiran, ketepatan penangkapan isi bacaan dan kosentrasi. Tingkat penguasaan kebahasaan yang cukup memadai. Jika tidak, komunikasi yang dilakukan tidak akan berjalan lancar dan sempurna.

\section{HASIL DAN PEMBAHASAN}

Penelitian ini dilakukan pada 60 orang siswa kelas VII yang terdiri dari dua sekolah pada tahun pelajaran 2017- 2018, yaitu MTsN 13 dan MTsN 32 Jakarta Selatan. Penelitian ini terdiri dari tiga variabel, yaitu variabel kemampuan menyimak (X1), penguasaan kosakata (X2) sebagai variabel bebas, dan variabel keterampilan menulis deskripsi (Y) sebagai variabel terikat. Deskripsi hasil penelitian disajikan mencakup skor nilai tertinggi, skor terendah, simpangan baku, modus, median dan sebaran data. Deskripsi data dari tiap-tiap variabel adalah sebagai berikut:

\section{Tabel 1}

Deskripsi Data Hasil Penelitian

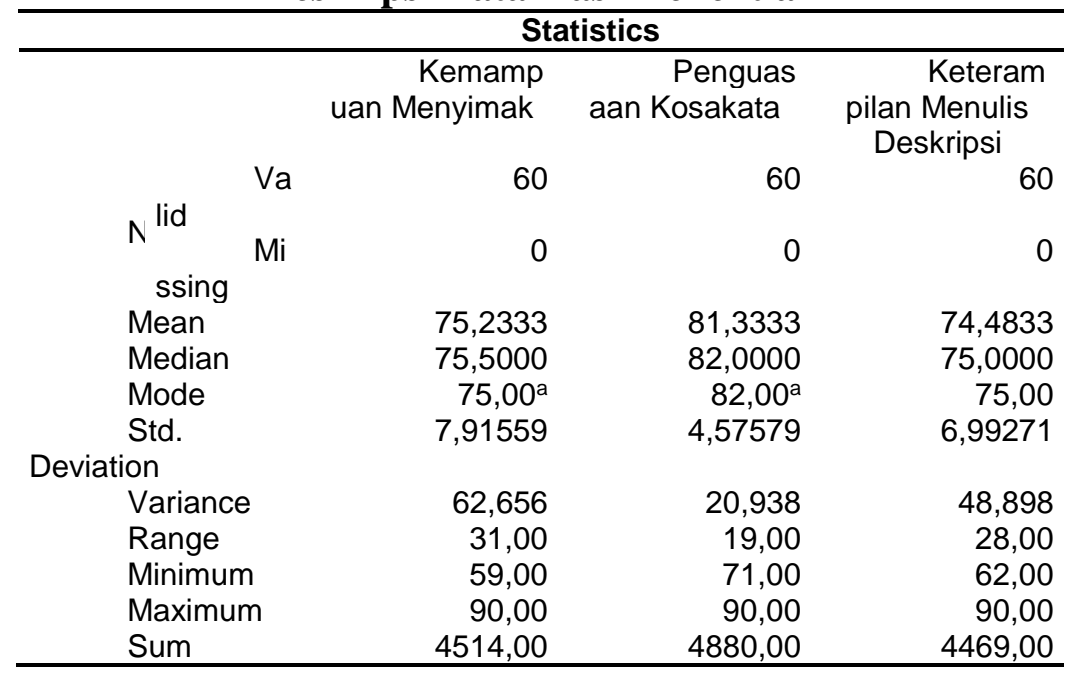

Berdasarkan data penelitian untuk kemampuan menyimak diperoleh hasil seperti pada tabel berikut :

Tabel 2

Data Statistik

\begin{tabular}{|c|c|c|}
\hline \multicolumn{3}{|c|}{ Statistics } \\
\hline \multicolumn{3}{|c|}{ Kemampuan } \\
\hline Menyir & & \\
\hline & Val & 60 \\
\hline$N^{i d}$ & Mi & 0 \\
\hline ssing & & \\
\hline Mean & & $\begin{array}{r}75 \\
2333\end{array}$ \\
\hline
\end{tabular}




\begin{tabular}{cr}
\hline Median & 75, \\
& 5000 \\
Mode & 75, \\
Std. & $00^{\mathrm{a}}$ \\
Deviation & 7,9 \\
Variance & 1559 \\
& 62, \\
Range & 656 \\
& 31, \\
Minimum & 00 \\
& 59, \\
Maximum & 00 \\
& 90, \\
Sum & 00 \\
& 451 \\
& 4,00 \\
\hline
\end{tabular}

Berdasarkan tabel di atas dapat dijelaskan bahwa rata-rata kemampuan menyimak mempunyai nilai yang hampir sama antara rata-rata dengan nilai tengah (median) yaitu 75,23 dan 75,50 dengan simpangan baku 7,91, skor minimum 59 dan skor maksimum 90. Banyaknya butir pertanyaan dalam instrument kemampuan menyimak adalah 30 butir pertanyaan dengan skor maksimum tiap butir pertanyaan adalah 5 dan skor minimumnya 1.

Data yang tertera pada tabel diatas juga diperoleh skor standar deviasi 7,91yang artinya bahwa selisih skor satu responden dengan responden lainnya mempunyai rata-rata 7,91 yang tidak terlalu besar. Dengan demikian variasi data kemampuan menyimak cukup ketat dan homogen.

Dari deskripsi tersebut, dapat dilihat antara nilai rata-rata dan median hampir sama yaitu 75,23dan 75,50. Hal ini menunjukkan bahwa data skor kemampuan menyimak pada penelitian ini cukup representativ. Sedangkan skor yang berada di atas rata-rata lebih banyak dibanding yang berada di bawah ratarata menunjukkan bahwa siswa yang mempunyai kemampuan menyimak tinggi lebih banyak dibanding yang rendah. Data di atas diperkuat dengan gambar histogram 4.1, sehingga dikatakan bahwa data variabel distribusi kemampuan menyimak mempunyai sebaran yang normal.

Berdasarkan data penelitian untuk penguasaan kosakata diperoleh hasil seperti pada tabel berikut :

\section{Tabel 3}

Data Statistik Penguasaan Kosakata

\begin{tabular}{|c|c|c|}
\hline & Stati & \\
\hline & $\begin{array}{r}\mathrm{Pe} \\
\mathrm{Kos}\end{array}$ & aan \\
\hline & Val & 60 \\
\hline$N^{i d}$ & $\mathrm{Mi}$ & 0 \\
\hline ssing & & \\
\hline Mean & & $\begin{array}{r}81, \\
3333\end{array}$ \\
\hline Median & & $\begin{array}{r}82 \\
0000\end{array}$ \\
\hline Mode & & $\begin{array}{l}82 \\
00^{\mathrm{a}}\end{array}$ \\
\hline Std. & & 4,5 \\
\hline Deviation & & 7579 \\
\hline
\end{tabular}




\begin{tabular}{lr}
\hline Variance & 20, \\
& 938 \\
Range & 19, \\
& 00 \\
Minimum & 71, \\
& 00 \\
Maximum & 90, \\
Sum & 00 \\
& 488 \\
& 0,00 \\
\hline
\end{tabular}

Berdasarkan tabel di atas dapat dijelaskan bahwa rata-rata penguasaan kosakata siswa mempunyai nilai yang hampir sama dengan nilai tengah (median) yaitu 81,33 dan 82 dengan simpangan baku 4,57, skor minimum 71 dan skor maksimum 90. Banyaknya butir pertanyaan dalam instrumen kemampuan penguasaan kosakata adalah 30 butir pertanyaan dengan skor maksimum tiap butir pertanyaan adalah 5 dan skor minimumnya 1 .

Data yang tertera pada tabel di atas diperoleh skor standar deviasi 4,57 yang artinya bahwa selisih skor satu responden dengan responden lainnya mempunyai rata-rata 4,57 yang tidak terlalu besar. Dengan demikian, variasi data penguasaan kosakata siswa cukup ketat dan homogen.

Berdasarkan deskripsi data tersebut, maka dapat dilihat antara nilai ratarata dan median hampir sama yaitu 81,33 dan 82 . Hal ini menunjukkan bahwa data skor penguasaan kosakata pada penelitian ini cukup representatif, sedangkan skor yang berada di atas rata-rata lebih banyak dibanding yang berada di bawah rata-rata menunjukkan bahwa siswa yang mempunyai penguasaan kosakata tinggi lebih banyak dibanding yang rendah. Data di atas diperkuat dengan gambar 4.2, sehingga dikatakan bahwa data distribusi penguasaan kosakata mempunyai sebaran yang normal.

Berdasarkan data penelitian untuk keterampilan menulis deskripsi diperoleh hasil seperti pada tabel berikut :

\section{Tabel 4}

\section{Data Statistik Keterampilan Menulis Deskripsi}

Statistics

Keterampilan

Menulis Deskripsi

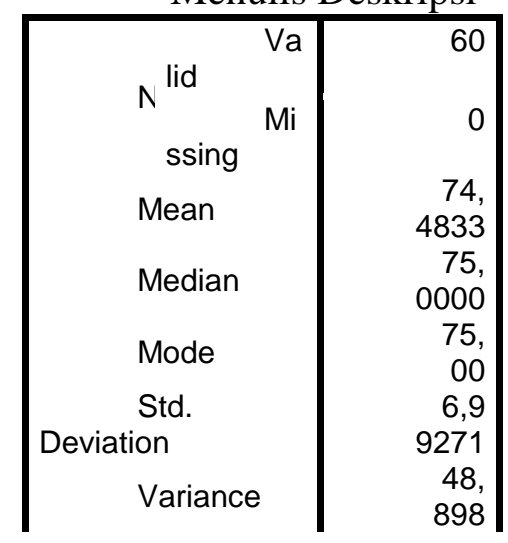




\begin{tabular}{|l|r|} 
Range & 28, \\
00 \\
Minimum & 62, \\
00 \\
90 \\
Maximum & 00 \\
& 446 \\
Sum & 9,00 \\
\hline
\end{tabular}

Berdasarkan tabel di atas dapat dijelaskan bahwa rata-rata keterampilan menulis deskripsi mempunyai nilai yang hampir sama antara rata-rata dengan nilai tengah (median) yaitu 74,48 dan 75 dengan simpangan baku 6,99, skor minimum 62 dan skor maksimum 90. Skor yang diperoleh ini merupakan hasil tes formatif yang dilakukan di sekolah dengan skor jawaban maksimal 100 dan minimal 0.

Data yang tertera pada tabel di atas juga diperoleh skor standar deviasi 6,99 yang artinya bahwa selisih skor satu responden dengan responden lainnya mempunyai rata-rata 6,99 yang tidak terlalu besar. Dengan demikian, variasi data keterampilan menulis deskripsi cukup ketat dan homogen.

Berdasarkan deskripsi data tersebut, maka dapat dilihat antara nilai ratarata dan median hampir sama yaitu74,48 dan 75 . Hal ini menunjukkan bahwa keterampilan menulis deskripsi pada penelitian ini cukup representatif. Sedangkan skor yang berada di atas rata-rata lebih banyak dibanding yang berada di bawah rata-rata menunjukkan bahwa siswa yang mempunyai keterampilan menulis deskripsi tinggi lebih banyak dibanding yang rendah. Data di atas diperkuat dengan gambar histogram 4.3, sehingga dikatakan bahwa data variabel distribusi keterampilan menulis deskripsi mempunyai sebaran yang normal.

Pengujian analisis regresi linear, baik linear sederhana maupun ganda harus memenuhi beberapa persyaratan analisis, persyaratan analisis tersebut adalah sebagai berikut:

Sampel yang berupa pasangan data sampel X1 dan X2 harus diambil acak dan memenuhi sampel minimum. Untuk setiap kelompok harga prediktor X1 yang diberikan, respon X2 harus independen dan berdistribusi normal.

Bentuk regresi adalah linear. Persyaratan pertama telah terpenuhi, sebab sampel penelitian ini telah diambil acak dengan ukuran sampel sebanyak 60 orang siswa. Sementara itu, untuk persyaratan keempat yakni syarat bentuk linear persamaan regresi pengujiannya dilakukan secara bersama-sama dengan pengujian hipotesis.

Langkah selanjutnya, setelah diuraikan deskripsi data hasil penelitian sebelum hipotesis diuji kebenarannya, maka terlebih dahulu dilakukan uji persyaratan, antara lain mengenai uji normalitas sampel, uji homogenitas dan uji lineritas data variabel penelitian. Penelitian tersebut dilakukan untuk mengetahui kenormalan, hegomogenan dan liniernya data yang akan diolah untuk mengetahui hubungan masing-masing variabel. Dengan demikian, data hasil penelitian tersebut dapat diketahui sudah memenuhi persyaratan atau belum memenuhi persyaratan.

Uji Normalitas dilakukan pada data variabel bebas (pada kemampuan menyimak dan penguasaan kosakata) serta variabel terikat (keterampilan menulis 
deskripsi). Pengujian normalitas data masing-masing variabel sampel diuji melalui hipotesis berikut:

Ho : data pada sampel tersebut berdistribusi normal

$\mathrm{H} 1$ : data pada sampel tersebut tidak berdistribusi normal

Perhitungan uji normalitas dilakukan dengan bantuan komputer melalui program aplikasi SPSS 22. Menurut ketentuan yang ada pada program tersebut, maka kriteria dari normalitas data adalah jika " $p$ value (sig)> 0,05, maka Ho diterima", yang berarti data pada sampel tersebut berdistribusi normal. Nilai $p$ value (sig) adalah bilangan yang tertera pada kolom sig dalam tabel hasil atau output perhitungan pengujian normalitas oleh program SPSS. Dalam hal ini, digunakan metode Kolmogorov-Smirnov. Hasil perhitungan bisa dilihat pada tabel 4.5 sebagai berikut :

Tabel 5

Hasil Pengujian Normalitas Data

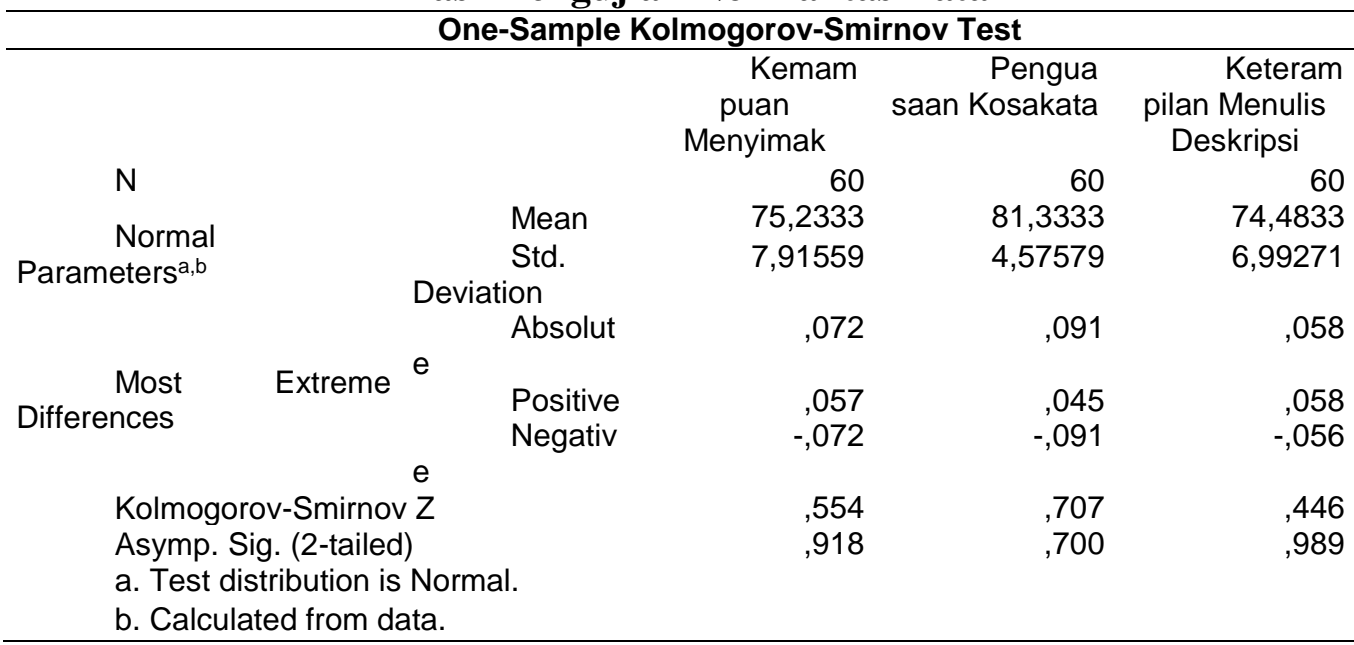

Dari tabel di atas, dapat diketahui nilai sig pada kolom kolmogorovSminov untuk variabel kemampuan menyimak (X1) sebesar 0,918, penguasaan kosakata (X2) sebesar 0,700, dan untuk variabel keterampilan menulis deskripsi (Y) sebesar 0,989. Jika dibandingkan dengan kriteria pengujian, maka ketiga variabel tersebut memenuhi kriteria atau berdistribusi normal karena nilai sig > 0,05. Untuk memperkuat hasil pengujian tersebut maka ditampilkan grafik Normal Q-Q Plot untuk setiap sampel. Dengan demikian maka data tersebut dapat diteruskan untuk uji selanjutnya.

Uji linearitas dilakukan untuk melihat apakah persamaan regresi $\mathrm{Y}=\mathrm{a}+$ bX berbentuk linear. Dalam analisis ini, menggunakan program SPSS 22 untuk menentukan persamaan regresi linear atau tidak dengan melihat koefisien $P$-value pada baris Deviation from linearity, yaitu apabila koefisien $P$-value lebih besar dari taraf signifikan 0,05 , maka persamaan regresi berbentuk linear. Sebaliknya, apabila koefisien $P$-value lebih kecil dari taraf signifikan 0,05, maka persamaan regresi berbentuk tidak linear.

Berikut adalah tabel hasil analisis terhadap uji linearitas regresi yang dilakukan dengan bantuan program SPSS 22 sebagai berikut : 
Tabel 6

Uji Linearitas Regresi Kemampuan Menyimak dan Keterampilan Menulis Deskripsi

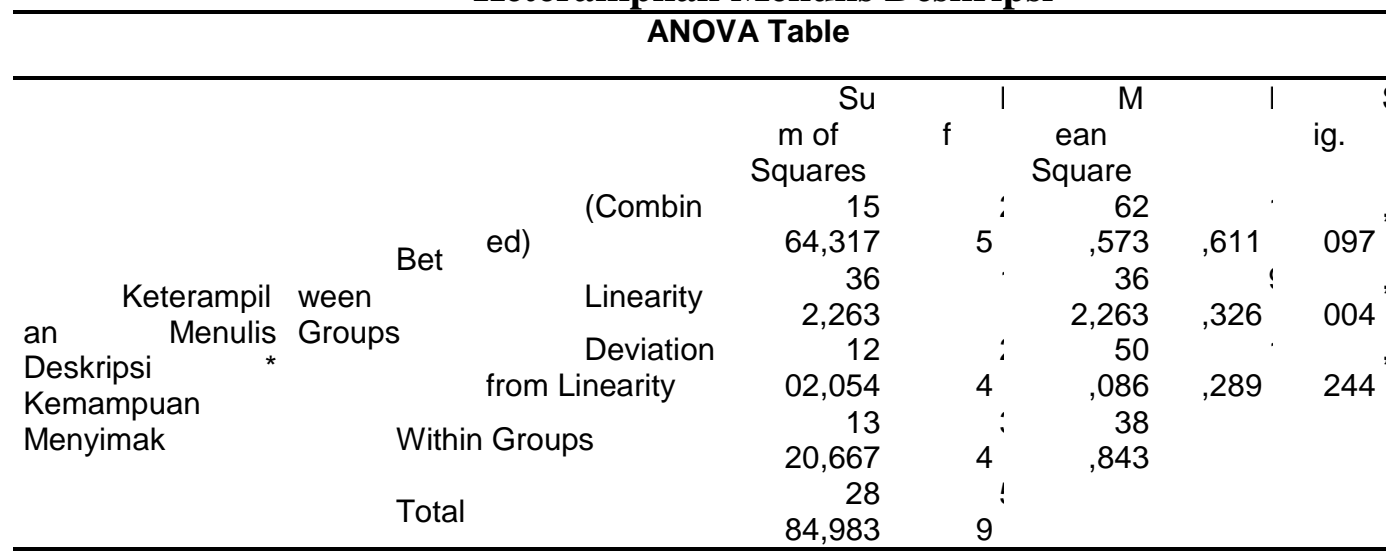

Dari tabel di atas, diketahui baris Deviation from linearity memiliki nilai sig sebesar 0,244 lebih besar dari 0,05, maka dapat disimpulkan bahwa bentuk persamaan regresi kemampuan menyimak dan keterampilan menulis deskripsi adalah linear.

Berikut adalah tabel hasil analisis terhadap uji linearitas regresi yang dilakukan dengan bantuan program SPSS 22 sebagai berikut:

\section{Tabel 7}

Uji Linearitas Regresi Penguasaan Kosakata dan Keterampilan Menulis

Deskripsi

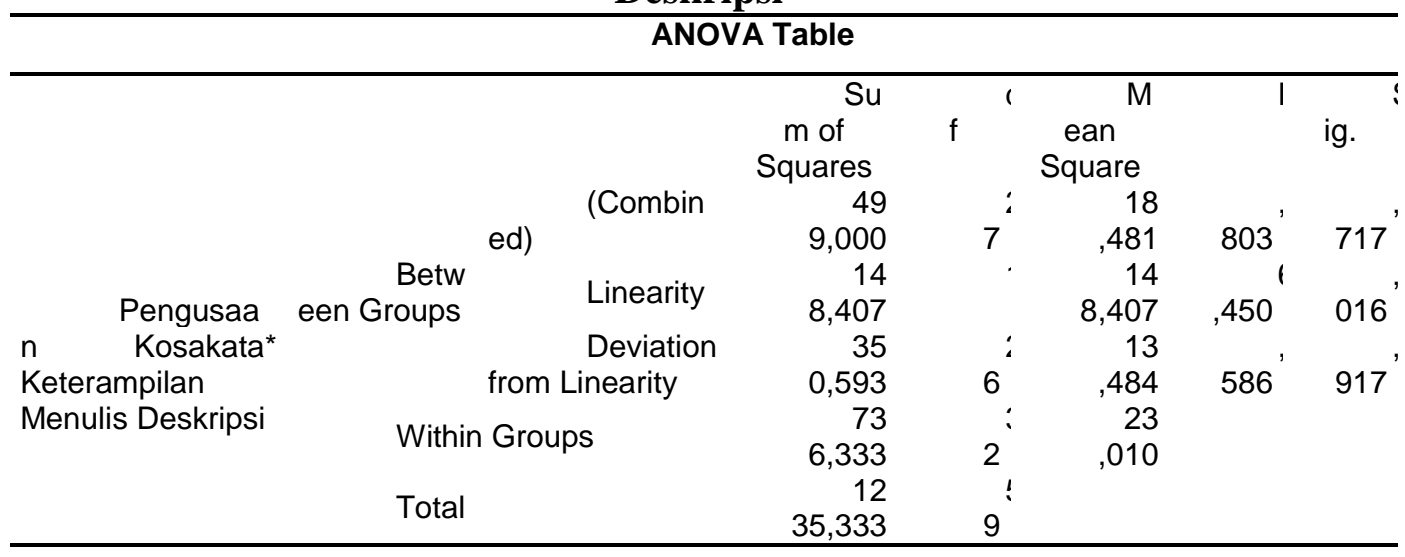

Dari tabel di atas diketahui baris Deviation from linearity memiliki nilai sig sebesar 0,917 lebih besar dari 0,05, maka dapat disimpulkan bahwa bentuk persamaan regresi penguasaan kosakata dan keterampilan menulis deskripsi adalah linear.

\section{Tabel 8}

\section{Data Variabel X1 dan X2 terhadap Y}

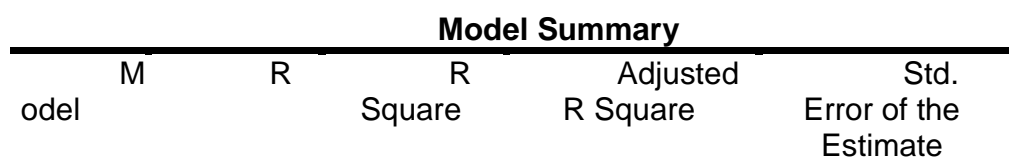


Diskursus: Jurnal Pendidikan Bahasa Indonesia

Vol. 1, No. 1, April 2018, pp. 52-66

p-ISSN: 2615-4935

e-ISSN: 2615-4943

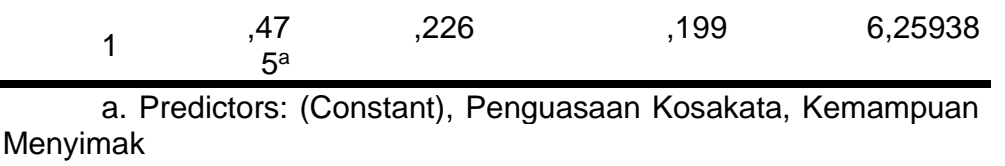

Tabel 9

Data Anova X1 dan X2 terhadap Y

\begin{tabular}{|c|c|c|c|c|c|c|}
\hline \multicolumn{7}{|c|}{ ANOVA $^{a}$} \\
\hline Model & & $\begin{array}{l}\text { Sum of } \\
\text { Squares }\end{array}$ & Df & $\begin{array}{l}\text { Mean } \\
\text { Square }\end{array}$ & & Sig. \\
\hline \multirow{3}{*}{${ }^{1}$ al } & Regre & 651,735 & 2 & 325,868 & $\begin{array}{r}8,3 \\
17\end{array}$ & $\begin{array}{r}, 00 \\
1^{\mathrm{b}}\end{array}$ \\
\hline & Residu & 2233,248 & 57 & 39,180 & & \\
\hline & Total & 2884,983 & 59 & & & \\
\hline
\end{tabular}

a. Dependent Variable: Keterampilan Menulis Deskripsi

b. Predictors: (Constant), Penguasaan Kosakata, Kemampuan Menyimak

Tabel 10

Koefisien Regresi Pengaruh Variabel X1 dan X2 terhadap Y

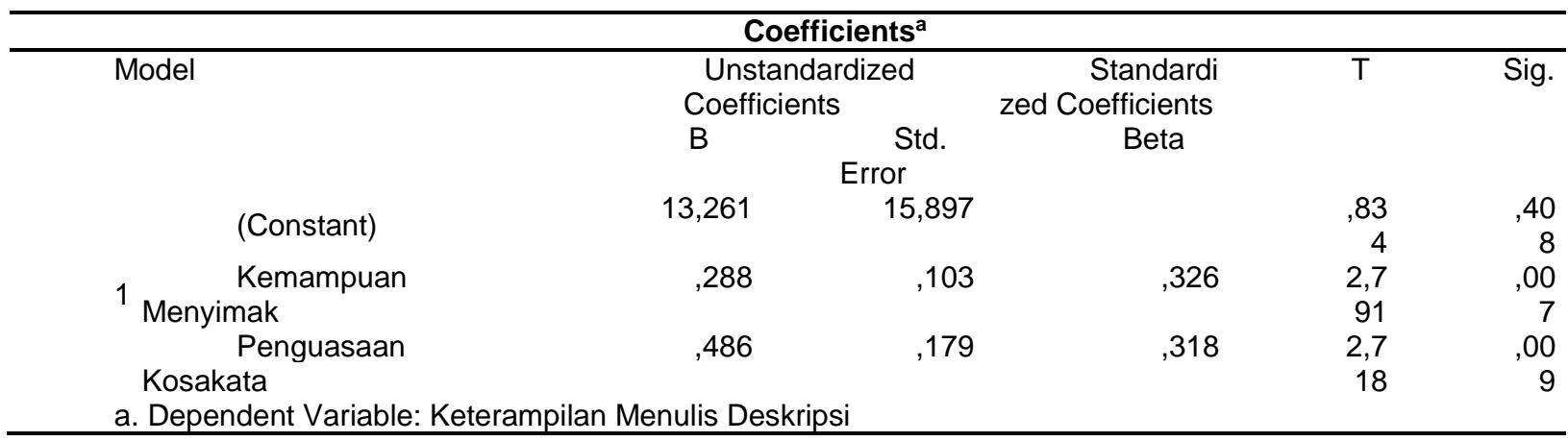

Dari tabel di atas, terlihat bahwa koefisien korelasi ganda pengaruh variabel bebas kemampuan menyimak (X1) dan penguasaan kosakata (X2) secara bersama-sama terhadap keterampilan menulis deskripsi (Y) adalah sebesar 0,475.

Perhitungan pengujian signifikansi koefisien korelasi ganda ini bisa dilihat pada tanda signifikan (a) pada kolom R. Berdasarkan perhitungan tersebut, maka diperoleh bahwa koefisien korelasi tersebut signifikan, dengan kata lain bahwa terdapat pengaruh yang signifikan variabel bebas kemampuan menyimak (X1) dan penguasaan kosakata (X2) secara bersama-sama terhadap keterampilan menulis deskripsi (Y), sedangkan koefisien determinasinya sebesar 22,6\%, menunjukkan bahwa besarnya kontribusi kemampuan menyimak (X1) dan penguasaan kosakata (X2) secara bersama-sama terhadap keterampilan menulis deskripsi (Y) adalah sebesar 22,6\%, sisanya 77,4\% karena pengaruh faktor lain. Untuk pengujian hipotesis melalui analisis regresi diperoleh hasil perhitungan terlihat pada tabel diperoleh persamaan garis regresi yang merepresentasikan pengaruh variabel X1 dan X2 terhadap variabel $Y$, yaitu $Y=13,261+0,288 X 1+$ $0,486 \times 2$.

Menurut ketentuan yang ada, kriteria signifikansi regresi tersebut adalah "jika Sig < 0.05, maka Ho ditolak" atau "jika Fhitimg> Ftabel, maka Ho ditolak", 
yang berarti bahwa koefisien regresi tersebut signifikan, dengan kata lain terdapat pengaruh yang signifikan variabel bebas $\mathrm{X} 1$ dan $\mathrm{X} 2$ terhadap variabel terikat $\mathrm{Y}$. Nilai Sig adalah bilangan yang tertera pada kolom Sig dalam tabel. Nilai Fhitimg adalah bilangan yang tertera pada kolom $\mathrm{F}$ dalam tabel, sedangkan nilai $\mathrm{F}$ tabel adalah nilai tabel distribusi $\mathrm{F}$ untuk taraf nyata $5 \%$ dengan derajat pembilang $(\mathrm{k})=$ 2 dan derajat penyebut $(\mathrm{n}-\mathrm{k}-1)=57$ dimana $\mathrm{n}$ adalah banyaknya responden, dan $\mathrm{k}$ adalah banyaknya variabel bebas.

Berdasarkan tabel, terlihat bahwa nilai Sig $=0.001<0,05$ dan Fhitung $=$ 83,17, maka Ho ditolak yang berarti bahwa koefisien regresi tersebut signifikan. Dengan kata lain, bahwa terdapat pengaruh yang signifikan variabel kemampuan menyimak (X1) dan penguasaan kosakata (X2) secara bersama-sama terhadap keterampilan menulis deskripsi (Y). Dari hasil pengujian korelasi maupun regresi tersebut, maka bisa disimpulkan bahwa terdapat pengaruh yang signifikan variabel kemampuan menyimak (X1) dan penguasaan kosakata (X2) secara bersama-sama terhadap keterampilan menulis deskripsi (Y).

Berdasarkan persamaan regresi ganda menunjukkan bahwa hipotesis statisrik Ho: Tidak ada pengaruh variabel bebas kemampuan menyimak (X1) terhadap keterampilan menulis deskripsi (Y). Ditolak karena nilai sig $=0.007<$ 0.05 dan thitung $=2,791$, maka Ho ditolak yang berarti bahwa koefisien regresi tersebut signifikan variabel bebas X1 (kemampuan menyimak) terhadap variabel terikat Y (keterampilan menulis deskripsi). Dari hasil pengujian korelasi maupun regresi tersebut, dapat disimpulkan bahwa terdapat pengaruh yang signifikan variabel kemampuan menyimak (X1) terhadap keterampilan menulis deskripsi (Y).

Berdasarkan persamaan regresi ganda menunjukkan bahwa hipotesis statistik Ho : Tidak ada pengaruh variabel penguasaan kosakata (X2) terhadap variable keterampilan menulis deskripsi $(\mathrm{Y})$, ditolak karena nilai sig $=0.009<$ 0.05 dan thitung $=2,718$. Hal ini berarti, H1 diterima. Artinya hipotesis penelitian yang menyatakan bahwa ada pengaruh penguasaan kosakata terhadap keterampilan menulis deskripsi dapat diterima.

Berdasarkan hasil pengujian korelasi maupun regresi tersebut, maka bisa disimpulkan bahwa terdapat pengaruh yang signifikan variabel penguasaan kosakata (X2) terhadap keterampilan menulis deskripsi (Y).

Untuk mengetahui pengaruh antara kemampuan menyimak (X1) dan penguasaan kosakata (X2) secara bersama-sama terhadap keterampilan menulis deskripsi (Y), maka persamaan regresi telah memenuhi persyaratan yang diperlukan antara lain variabel dependen mengikuti distribusi normal, dan hasil uji linearitas diperoleh persamaan regresi variabel dependent terhadap variabel independent adalah linear, begitu juga hasil uji multikolinearitas dapat dikatakan tidak terjadi multikolinearitas.

Dari deskripsi data setelah dilakukan analisis korelasi diperoleh koefisien korelasi sebesar 0,475 dan koefisien determinasi sebesaar 22,6\%. Setelah dilakukan pengujian dengan program SPSS, terbukti bahwa koefisien korelasi tersebut signifikan. Hal ini berarti bahwa terdapat pengaruh variabel bebas kemampuan menyimak dan penguasaan kosakata secara bersama-sama terhadap variabel terikat keterampilan menulis deskripsi. 
Berdasarkan hasil analisis regresi, maka diperoleh persamaan garis regresi ganda $Y=13,261+0,288 X 1+0,486 X 2$. Nilai konstanta $=13,261$, menunjukkan bahwa siswa yang penguasaan menyimak dan penguasaan kosakata paling rendah sulit untuk bisa meraih prestasi belajar yang baik. Sedangkan nilai koefisien regresi sebesar 0,288 dan 0,486 , menunjukkan bahwa terdapat pengaruh positif variabel bebas X1 kemampuan menyimak dan penguasaan kosakata (X2) secara bersama-sama terhadap variabel terikat (Y) keterampilan menulis deskripsi. Setiap kenaikan satu unit kemampuan menyimak dan sekaligus dengan kenaikan satu unit variabel penguasaan kosakata akan diikuti dengan kenaikan keterampilan menulis deskripsi sebesar 0,776 unit $=(0,288+0,486)$.

Dari pengujian signifikansi koefisien regresi yang juga dilakukan dengan program SPSS, diperoleh bahwa koefisien regresi tersebut signifikan, yaitu ditunjukkan oleh nilai Sig $=0.000<0,05$ dan Fhitung $=83,17$, yang berarti benar bahwa terdapat pengaruh yang positif variabel bebas X1 (kemampuan menyimak) dan X2 (penguasaan kosakata) secara bersama-sama terhadap variabel terikat $\mathrm{Y}$ (keterampilan menulis deskripsi).

Berdasarkan informasi kuantitatif dan teori tersebut peneliti berkesimpulan bahwa kemampuan menyimak dan penguasaan kosakata mempunyai pengaruh yang positif dan signifikan secara bersama-sama terhadap keterampilan menulis deskripsi.

Dari pengujian hipotesis diperoleh bahwa nilai Sig $=0.007$ dan $\mathrm{t}$ hitung $=$ 2,791, maka Ho ditolak yang berarti terdapat pengaruh yang signifikan variabel bebas X1 (kemampuan menyimak) terhadap variabel terikat Y (keterampilan menulis deskripsi). Hasil penelitian menunjukkan bahwa ada pengaruh kemampuan menyimak terhadap keterampilan menulis deskripsi. Setiap kenaikan satu unit kemampuan menyimak akan diikuti dengan kenaikan keterampilan menulis deskripsi siswa sebesar 0,288 unit, ceteris paribus atau variabel kemampuan menyimak tidak berubah.

Berdasarkan informasi kuantitatif dan teori tersebut, maka peneliti menyimpulkan bahwa terdapat pengaruh yang signifikan kemampuan menyimak terhadap keterampilan menulis deskripsi.

Dari pengujian hipotesis berarti diperoleh bahwa nilai Sig $=0,009$ dan thitung $=2,718$, maka Ho ditolak yang terdapat pengaruh yang signifikan variable bebas X2 (penguasaan kosakata) terhadap variabel terikat $\mathrm{Y}$ (keterampilan menulis deskripsi).

Berdasarkan hasil pengujian dinyatakan ada pengaruh variable penguasaan kosakata terhadap variable keterampilan menulis deskripsi. Setiap kenaikan satu unit penguasaan kosakata akan diikuti dengan kenaikan keterampilan menulis deskripsi sebesar 0.486 unit, ceteris paribus atau variabel pengaruh penguasaan kosakata tidak berubah.

Dari informasi kuantitatif dan teori tersebut maka peneliti berasumsi bahwa terdapat pengaruh signifikan penguasaan kosakata terhadap keterampilan menulis deskripsi 


\section{SIMPULAN}

Berdasarkan deskrispsi data penelitian dan setelah dilakukan analisis, maka dapat disimpulkan:

1. Terdapat pengaruh yang signifikan kemampuan menyimak dan penguasaan kosakata secara bersama-sama terhadap keterampilan menulis deskripsi siswa MTs Negeri di Jakarta Selatan. Hal ini dibuktikan dengan nilai Sig = 0,001 $<0,05$ dan Fhitung = 83,17.

2. Terdapat pengaruh yang signifikan kemampuan menyimak terhadap keterampilan menulis deskripsi siswa MTs Negeri di Jakarta Selatan. Hal ini dibuktikan dengan nilai Sig $=0,007<0,05$ dan thitung $=2,791$.

3. Terdapat pengaruh yang signifikan penguasaan kosakata terhadap keterampilan menulis deskripsi siswa MTs Negeri di Jakarta Selatan . Hal ini dibuktikan dengan nilai Sig $=0,009<0,05$ dan thitung $=2,718$.

\section{DAFTAR PUSTAKA}

Arikunto, S. (2009). Evaluasi program pendidikan. Jakarta: Bumi Aksara

Iskandarwassid \& Sunendar, Dadang. (2015). Strategi pembelajaran bahasa. Bandung: PT Remaja Rosdakarya.

Mulyasa, E. (2009). Menjadi guru profesional menciptakan pembelajaran kreatif dan menyenangkan. Bandung: Remaja Rosdakarya.

Nazir,M. (2003). Metode penelitian. Jakarta: Ghalia Indonesia.

Ridwan. (2004), Metode dan teknik menyusun tesis, Alfabeta Bandung

Suprayekti.(2003). Interaksi belajar mengajar. Jakarta. Direktorat Tenaga Kependidikan

Tarigan, H.G.(2008).Menulis sesabadsuatu keterampilan berbahasa, Bandung : Angkasa

Umar, H. (2009). Metode penelitian untuk skripsi dan tesis bisnis. Jakarta:

Rajawali Persada

Wagiran.(2005). Curah gagasan pengantar penulisan karya ilmiah. Semarang:

Rumah Indonesia

Kasno.2014.http://journal.sktipnurulhuda.ac.id/index.php/utility. (dalamhttp:// yang diunduh tanggal 18 Maret 2018) 